DOI 10.37882/2223-2982.2020.10.31

\title{
ОПЫТ РАЗВИТИЯ СТУДЕНЧЕСКОГО ВОЛОНТЕРСТВА И ОБУЧЕНИЯ ВОЛОНТЕРОВ В ТУВИНСКОМ ГОСУДАРСТВЕННОМ УНИВЕРСИТЕТЕ
}

\section{EXPERIENCE IN THE DEVELOPMENT OF STUDENT VOLUNTEERING AND TRAINING VOLUNTEERS IN THE TUVIN STATE UNIVERSITY}

M. Sergeeva

Summary: This article reveals the activities of student volunteers on the example of THE Tuva state University (hereinafter - Tuvsu). The system of organization of volunteer work is described. The main problems and directions of development of volunteer activity in higher education institutions are considered.

Keywords: student youth, student self-government, volunteer movement, motives for involvement in volunteer activities, University, volunteer center.
Сергеева Мария Николаевна

К.культурологии, Тувинский государственный университет, г. Кызыл mashaist@mail.ru

Аннотация: Данная статья раскрывает деятельность студентов-волонтеров на примере ФГБОУ В0 «Тувинский государственный университет» (далее ТувГУ). Описана система организации волонтерской работы. Рассмотрены основные проблемы и направления развития волонтерской деятельности в высшем учебном заведении.

Ключевые слова: студенческая молодёжь, студенческое самоуправление, волонтёрское движение, мотивы вовлечения в волонтёрскую деятельность, вуз, волонтерский центр.
B олонтёрское движение в России стало частью общества. Молодежь республики Тыва активно принимает участие в волонтерских движениях в регионе. В ФБОУ ВО «Тувинский государственный университет» студенты-волонтеры являются неисчерпаемым ресурсом для реализации разных социально-профильных проектов, которые подкрепляются практической значимостью для будущей трудовой деятельности учащихся. Основной целью молодежной политики в университете является вовлечение студентов в социальную практику путем развития добровольческой деятельности. Волонтерское движение в университете направлено на профилактическую работу со студентами по предупреждению девиантного поведения. Волонтерское движение помогает университету создать благоприятный имидж на федеральном и региональном уровнях, выявить наиболее активных, талантливых и ответственных студентов, развивать связи с региональными и муниципальными властями и общественными организациями.

Волонтерская деятельность в ФБОУ ВО «Тувинский государственный университет» имеет свою историю. Само волонтерское движение начиналось с экологического отряда «Капелька». Из-за большой активности студентов в 2010 году были созданы еще два отряда, это волонтерский отряд «Данко» с педагогическим направлением, который в большей степени оказывал помощь детям и пожилым людям, и отряд правопорядка «Ирбис», который сопровождал все мероприятия и организовывал рейды в общежитиях для соблюдения правил проживания. Студенты вуза, участвующие в волонтерской деятельности, более активно формируют свой профессиональный менталитет, так как выбранные ими направления нацелены на их род профессиональной деятельности.

В 2019 году университет открывает волонтерский центр «Данко», в который вошли 5 волонтерских отрядов, а в 2020 году подписывает соглашение и вступает в Ассоциацию волонтерских центров - крупнейшую волонтерскую организацию в России. Она создана в 2014 году по инициативе президента Владимира Владимировича Путина с целью сохранить наследие волонтерской программы Олимпийских игр в Сочи и развивать добровольческое движение в целом.

Система организации волонтерской деятельности вузе начинается с поиска и обучения студентов-волонтеров. При отборе волонтёров используются следующие методы:

- анкетирование обычно проводится на начальной стадии работы по программе или в процессе ее реализации, когда появляются новые волонтёры;

- тестирование позволяет собрать дополнительную информацию о волонтёре, составить его психологический портрет;

- собеседование позволяет лучше познакомиться с волонтёром, выяснить, какие у него интересы и способности.

Для обеспечения данной деятельности и достижения высокого качества волонтерской работы университет организует и проводит образовательные мероприятия, 
такие как «Школы волонтеров» и «Образовательный марафон». В рамках мероприятий разрабатываются тренинговые программы и учебно-методические материалы Управления молодежной политики вуза. Программы обучения, направленные на формирование общекультурных компетенций волонтеров, включают в себя следующие модули: умение ориентироваться в различных ситуациях, приветливость и дружелюбие, желание оказать содействие, коммуникабельность, умение работать в команде, ответственность и исполнительность. Обучение в вузе осуществляется в следующих форматах:

1. Очно-дистанционное обучение волонтеров организуется на территории вуза или в социальных сетях в режиме онлайн. Образовательный модуль включает в себя лекции, решение кейсов и другие формы проведения занятий. Волонтеры ТувГУ проходят обучение на готовых образовательных платформах:

Добро. Университет. - https://edu.dobro.ru/, Онлайн курсы Школы социального волонтерства - http://online.volonter-school.ru/, Академия АВЦ. Школа - http://тырешаешь.pф/volonteers, «Узнай.PRO»- https://добровольцыроссии.рф/ news/878-zapusheny-onlajn-kur и т.д.

2. Обучение на практике по профилю отряда. Данный вариант включает практические занятия на событийных мероприятиях, тестовых занятиях и других направлениях работы, где волонтеры смогут закрепить свои навыки и знания.

Развитие волонтера зависит от его мотивации. К волонтерству можно прийти по многим причинам. Есть студенты, которым нравится помогать или быть организаторами мероприятий, их сразу можно заметить. Они активно включаются в данный процесс, у них налаживается личный контакт, и это очень ценно, они быстро раскрываются и расцветают. Также есть студенты, которым хочется побывать на волонтерских мероприятиях. Волонтерство - это очень сложная вещь, важно, чтобы координатор не давил на волонтеров, не говорил им, что они обязаны или должны это делать. Хотелось бы отметить, что множество этапов волонтерства и мотивация человека тесно связаны. Потому что те волонтеры, которые приходят в центр, часто становятся опорой группы и координаторами. Период спада активности сильно зависит от мотивации. Слабая мотивация видна сразу, и она является причиной не очень ответственного поведения и редких посещений. А если у волонтера сильная мотивация, то он активно включается в жизнь группы, старается не пропускать собраний, и только изменение жизненных обстоятельств может вынудить его покинуть организацию.

Поэтом в ТувГУ разработаны механизмы мотивации волонтеров:
1. Социальная мотивация строится на основе контактов с другими людьми. К социальной мотивации относятся: желание включиться в новый круг общения; возможность найти единомышленников; стремление к общению и обмену опытом; потребность в чувстве принадлежности и необходимости; потребность играть роль в обществе и иметь цель в жизни.

2. Социальная ответственность основывается на убеждении, что если у человека есть возможность, то он обязательно должен помогать тем, кто находится в более сложной ситуации. К социальной мотивации относятся: желание улучшить жизнь людей в обществе; следование традиции оказания помощи нуждающимся людям; желание быть моделью поведения для других; желание показать свое неравнодушие к проблеме.

3. Материальная мотивация - достижение личных целей и/или удовлетворение личных потребностей: применение собственного опыта, знаний, навыков и приобретение новых; подготовка к работе, улучшение своего резюме, приобретение новых профессиональных контактов; возможность зачесть какие-либо предметы в институте; самореализация, личностный рост, самоутверждение; выполнение работы, приносящей удовольствие; интересное времяпрепровождение; компенсация отсутствия чего-либо в личной жизни.

В качестве нематериальных форм поощрения деятельности волонтеров в вузе применяются следующие: церемонии награждения лучших волонтеров; благодарственные письма с подписью ректора, проректора, возможность зачесть волонтерство в качестве практики или стажировки; отражение деятельности волонтера в публикациях на портале вуза и в других средствах массовой информации, с которыми взаимодействует прессслужба университета. Предоставляется возможность участвовать в крупных мероприятиях за пределами республики Тыва, а также возможность познакомиться с новыми людьми и завести друзей. Один из самых важных механизмов стимулирования волонтеров - это оказание материальной помощи через стипендиальный фонд.

Заключительный этап работы волонтера в центре оценка его деятельности. Она включает в себя большое количество проектов и мероприятий по направлениям деятельности волонтерского центра, объем привлеченных спонсорских средств, публикации в СМИ о волонтерской деятельности в вузе, отзывы организаторов, посетителей мероприятий о деятельности волонтеров (благодарственные письма, дипломы) и т.д.

Хотелось бы отметить, что, кроме красиво описанного процесса, имеется ряд проблем развития волонтерской деятельности в университете, одной из наиболее 
важных проблем является статус волонтерской деятельности, снижение интереса среди молодежи к волонтерской деятельности и низкая социальная активность, отсутствие навыков и интереса у студентов в подготовке и реализации волонтерских проектов.

На сегодняшний день волонтерский центр «Данко» ставит перед собой ряд приоритетных задач, которые помогут в решении проблем: пропаганда идей и ценностей волонтерства среди студентов первого-второго курсов, разработка и внедрение электронных курсов обучения и игровых проектов.

Студенческие волонтерские отряды организуют свою деятельность в рамках проектов следующих типов:

1. гуманитарные проекты;

2. социально-культурные проекты;

3. информационно-консультативные проекты студентов;

4. экологические проекты.

С 2019 года в университете проводится конкурс социальных проектов «Хрустальное сердце», были реализованы 27 социально-значимых проектов в 6 направлениях. Например, такие как «Волонтеры Анти-СПИД», «Чистый город», «Чистый Енисей» и т.д. Первое место получил проект Кызылского педагогического института «От сердца к сердцу» в номинации «Доброволец ТувГУ». Второе место в номинации «Отважное сердце» получил проект «Безопасное движение» поисково-спасательного отряда «Дуза» волонтеров естественно-географического факультета. Третье место заняли два проекта: «Подари Надежду!» исторического факультета и «Делай добро!» филологического факультета.

Волонтеры студенческого отряда «Дуза» в числе группы «Молодежка ОНФ» работали волонтерами в Иркутской области в п. Соляная Тайшетского района. Они помогали разбирать завалы, восстанавливать объекты инфраструктуры, оказывали адресную помощь пострадавшим. Поисково-спасательный отряд «Дуза» в декабре 2019 года организовывал профориентационную работу в Пий-Хемском и Кызылском кожуунах со школьниками. Студенты провели теоретические и практические занятия по вопросам оказания первой медицинской помощи. Приняли участие в акции «Внимание, дети» совместно с сотрудниками отделения УГИБДД МВД Республики Тыва и Тувинского регионального отделения «РОССОЮЗСПАС», где волонтеры отряда обеспечивали безопасность детей на дорогах г. Кызыла, а также призывали водителей быть бдительными на дороге, особенно вблизи школ. В рамках профилактических мероприятий поисково-спасательный отряд «Дуза» провел занятия по пожарной безопасности в школе № 1 им. Бухтуева г. Кызыла. Цель акции - уменьшить количество пожаров и обучить детей правилам безопасности.
В течение года студенты-волонтеры принимали активное участие в многочисленных благотворительных акциях по оказанию помощи детям из приюта, Дома малютки, Детского дома, школы-интерната г. Кызыла и детям из малообеспеченных семей. Традиционными стали такие волонтерские акции, как «Помоги собраться в школу», «Всемирный день без табака», «Подарок под елку», «100 добрых дел», «Помоги ветерану», «Белая ромашка» и т.д.

Волонтерский экологический отряд «Капелька» осенью и весной организует и проводит акции по уборке прилегающих к вузу территорий, участвует в акциях «Чистый город», «День Енисея», «Мы за чистый Кундустуг», «Чистые озера», «Поможем вместе!», «Чистые берега». За 2019 год волонтеры приняли участие в 47 экологических и 20 благотворительных акциях, организовали и провели 11 военно-патриотических мероприятий, совершили 240 добрых дел.

В 2019 году волонтерский отряд «Данко» стал победителем в конкурсе «Лучшая общественная молодежная организация».

Волонтер Милени Ким вошла в число 140 лучших добровольцев страны, приняла участие в Параде Победы на Красной площади в Москве, сопровождала народное шествие «Бессмертный полк».

Два творческих волонтерских направления Благотворительные спектакли студенческого театрального кружка «Буура» и Клуб творческой мастерской для молодежи «Decor» в 2019 году получили поддержку по линии Федерального агентства по делам молодежи (Росмолодежь) на сумму 400000 тыс. рублей.

В нашем университете существуют волонтерские движения, охватывающие все факультеты, институт и колледж: студенческая психологическая служба и юридическая клиника, туристический волонтерский отряд «Монблан», волонтерский отряд правопорядка «Ирбис», поисково-спасательный отряд «Дуза», экологический отряд «Капелька» студенческий спортивный клуб «Ястребы Тувы». Таким образом, волонтерская деятельность призвана быть не просто стихийным порывом помогать, а должна подкрепляться практической значимостью для будущей трудовой деятельности студента.

Проанализировав деятельность волонтерского движения ТувГУ, было установлено, что его воспитательные возможности в развитии социальной активности студентов направлены на добровольчество. Для молодежи волонтерство - это чаще всего способ получить опыт и наладить связи, необходимые для будущей карьеры, а люди постарше считают добровольную помощь базовой жизненной ценностью. 
Таким образом, студенты-волонтеры ТувГУ приобретают социальный опыт: помогая представителям других социальных групп и сотрудничая с ними, волонтеры не только завязывают новые знакомства, но и учатся преодолевать стереотипы и барьеры, вызванные культурными различиями.

Также к результатам волонтерской деятельности относятся следующие:

\section{- рост профессиональных навыков.}

Студенты, участвовавшие в добровольческих проектах по своей специальности, признают, что стали намного глубже понимать материал, связывать теоретические знания с реальными проблемами и более четко представлять возможности своей будущей профессии.

- самопознание и саморазвитие

Работа в социально значимых проектах меняет мировоззрение, приоритеты и ценности людей, повышает осознанность.

\section{— повышение личной эффективности}

Успешно решая профессиональные задачи в команде единомышленников, волонтеры становятся увереннее в своих силах и учатся планировать и организовывать собственные проекты. В нашем вузе волонтерское движение укрепляет социальные связи между студентами различных факультетов на основе сотрудничества и совместного творчества. Студенты приобретают социальный опыт работы с разными категориями населения.

Добровольческая деятельность студенческой молодежи - это не только один из путей формирования и демонстрации гражданской позиции, но и одна из действенных форм активизации, организации и самореализации молодежи, освоение которой проходит в учебном заведении.

\section{ЛИТЕРАТУРА}

1. Загладина, Х.Т. Добровольчество (волонтёрство) как мощный фактор развития гражданской активности и успешной социализации детей и молодёжи / Х.Т. Загладина, Т.Н. Арсеньева // Воспитание школьников. - 2018. - № 1. - С. 16-22.

2. Захаренко, М.П. Молодёжное волонтёрство: версии существующие и перспективные / М.П. Захаренко // Современная библиотека. - 2017. - № 2. C. $45-47$

3. Зорина, Т.А. Повышение социальной активности посредством волонтёрской деятельности / Т.А. Зорина // Социальная работа. - 2017. - № 4. - С. $42-43$.

4. Иванова А.С. Добровольческий труд: сущность, функции, специфика // Социологические исследования. - 2011. - № 5. - С. 16.

5. Кобышева Л.И. Организация социально-педагогической деятельности студентов-волонтеров в условиях вуза // Научно-методический электронный журнал «Концепт». - 2016. - № 9 (сентябрь). - 0,5 п. л. - URL: http://e-kon-cept.ru/2016/16196.htm.

6. Лукьянова М.И., Грувер Н.В. Актуализация мотивации студентов образовательных учреждений к участию в волонтерской деятельности // Современные наукоемкие технологии. - 2017. - № 1. - C. 125-130; URL: http://top-technologies.ru/ru/article/view?id=36568 (дата обращения: 27.04.2020).

7. Певная, М.В. Студенческое волонтёрство: особенности деятельности и мотивации / М.В. Певная // Высшее образование в России. - 2015. - № 6. C. $81-88$.

8. Первушина, Е.А. Развитие волонтёрской деятельности в высших учебных заведениях / Е.А. Первушина // Высшее образование в России. - 2014. - № 11. - C. 112-117.

9. Прокопьева Ю.П., Прокопьева М.М. Мотивация волонтерской деятельности // Научно-методический электронный журнал «Концепт». - 2017. - Т. 6. C. 31-34. - URL: http://e-koncept.ru/2017/770019.htm.

(c) Сергеева Мария Николаевна (mashaist@mail.ru). 